Article

\title{
Carbon-supported ultrafine Pt nanoparticles modified with trace amounts of cobalt as enhanced oxygen reduction reaction catalysts for proton exchange membrane fuel cells
}

\author{
Xuejun Tang a,b, Dahui Fang a,b, Lijuan Qu a,b, Dongyan Xu c, Xiaoping Qin a, Bowen Qin a,b, Wei Song a, \\ Zhigang Shao ${ }^{\mathrm{a}, *}$, Baolian Yi ${ }^{\mathrm{a}}$ \\ a Fuel Cell System and Engineering Laboratory, Dalian Institute of Chemical Physics, Chinese Academy of Sciences, Dalian 116023, Liaoning, China \\ b University of Chinese Academy of Sciences, Beijing 100049, China \\ c State Key Laboratory Base of Eco-chemical Engineering, College of Chemical Engineering, Qingdao University of Science and Technology, Qingdao \\ 266042, Shandong, China
}

\section{A R T I C L E I N F}

\section{Article history:}

Received 1 December 2018

Accepted 11 January 2019

Published 5 April 2019

\section{Keywords:}

Proton exchange membrane fuel cells

Oxygen reduction reaction

Ultrafine Pt nanoparticles

Trace amounts of cobalt

Modified glycol method

Chemical etching strategy

\begin{abstract}
A B S T R A C T
To accelerate the kinetics of the oxygen reduction reaction (ORR) in proton exchange membrane fuel cells, ultrafine Pt nanoparticles modified with trace amounts of cobalt were fabricated and decorated on carbon black through a strategy involving modified glycol reduction and chemical etching. The obtained $\mathrm{Pt}_{36} \mathrm{Co} / \mathrm{C}$ catalyst exhibits a much larger electrochemical surface area (ECSA) and an improved ORR electrocatalytic activity compared to commercial Pt/C. Moreover, an electrode prepared with $\mathrm{Pt}_{36} \mathrm{Co} / \mathrm{C}$ was further evaluated under $\mathrm{H}_{2}$-air single cell test conditions, and exhibited a maximum specific power density of $10.27 \mathrm{~W} \mathrm{mg}_{\mathrm{Pt}^{-1}}$, which is 1.61 times higher than that of a conventional Pt/C electrode and also competitive with most state-of-the-art Pt-based architectures. In addition, the changes in ECSA, power density, and reacting resistance during the accelerated degradation process further demonstrate the enhanced durability of the $\mathrm{Pt}_{36} \mathrm{Co} / \mathrm{C}$ electrode. The superior performance observed in this work can be attributed to the synergy between the ultrasmall size and homogeneous distribution of catalyst nanoparticles, bimetallic ligand and electronic effects, and the dissolution of unstable Co with the rearrangement of surface structure brought about by acid etching. Furthermore, the accessible raw materials and simplified operating procedures involved in the fabrication process would result in great cost-effectiveness for practical applications of PEMFCs.
\end{abstract}

(C) 2019, Dalian Institute of Chemical Physics, Chinese Academy of Sciences. Published by Elsevier B.V. All rights reserved.

\section{Introduction}

Proton exchange membrane fuel cells (PEMFCs) are regarded as promising candidates for new-generation power sources, due to their high conversion efficiency and low envi- ronmental pollution. However, the sluggish kinetics of the oxygen reduction reaction (ORR) at the cathode hinders the wider application of PEMFCs. Owing to its extraordinary catalytic performance, platinum is an ideal electrocatalytic material for the ORR, but its scarcity and high cost limit the scaled produc-

\footnotetext{
* Corresponding author. E-mail: zhgshao@dicp.ac.cn

This work was supported by the National Major Research Project (2016YFB0101208), the National Natural Science Foundation of China (21576257), the Natural Science Foundation-Liaoning United Fund (U1508202), and the Strategic Priority Research Program of the Chinese Academy of Sciences (XDB06050303).
}

DOI: S1872-2067(19)63304-8 | http://www.sciencedirect.com/science/journal/18722067 | Chin. J. Catal., Vol. 40, No. 4, April 2019 
tion [1]. Thus, massive efforts have been devoted both to develop less expensive alternative catalysts, such as palladium-based [2] and non-precious metal [3] catalysts, and to improve the availability of Pt [4]. The latter strategy is generally implemented by fabricating ultrafine Pt nanoparticles (NPs) to maximize the effective surface areas for catalysis and minimize the required quantity of Pt. However, the large surface energy of the nanoparticles generally leads to severe agglomeration, thus weakening their practical performance. To avoid aggregation, surfactants with high molecular weight, such as polyvinylpyrrolidone (PVP), Pluronic F-127, and cetyltrimethyl ammonium bromide (CTAB) have been employed to stabilize the nanoparticles during the preparation process of Pt-based catalysts [5-7]. However, the elimination of these surfactants after the reaction is hard and complicated, and the residual portions around the nanoparticles would reduce the number of "clean" surface active sites, thus reducing the overall electrocatalytic activity of catalysts. Therefore, there is high interest in the design of a surfactant-free strategy for the synthesis of ultrafine Pt-based catalysts.

On the other hand, alloying Pt with transition metals (e.g., $\mathrm{Fe}, \mathrm{Co}, \mathrm{Ni}, \mathrm{Cu}, \mathrm{Mn}, \mathrm{Mo}$ ) can enhance the performance of Pt-based catalysts and reduce the mass requirements of $\mathrm{Pt}$, further improving the cost effectiveness [8-11]. Among various Pt-based bimetallic materials, Pt-Co has been shown to be one of the most effective catalysts for ORR, with superior electrocatalytic activity and stability [12]. According to previous studies, the enhanced catalytic performance of Pt-Co alloys is mainly attributed to geometric and electronic effects. In terms of geometric properties, the incorporation of Co into the Pt lattice during the alloying process would lead to compressive strain and hence shorten the Pt-Pt interatomic distance. Moreover, the electronic structure of the Pt-Co alloy would also be modified, owing to the difference in electronegativity between Pt and Co, which leads to a downshift of the $d$-band center. As a result, the adsorption of oxygenated species on the catalytic surface is reduced, and more effective active sites are created. Although the favorable features of the Pt-Co alloy make it a desirable electrocatalyst, some drawbacks still hinder its practical use. In particular, Co tends to dissolve during the electrochemical process, which would negatively affect the conductance of the membrane and severely degrade the effective performance of the catalyst in real PEMFC operation [13]. An acid etching pretreatment was proposed to address this problem. The selective leaching of non-noble metals from the alloy results in increased amounts of surface defects and higher roughness, while retaining the shorter Pt-Pt distance, which may result in better electrocatalytic activity. For example, Wang et al. [14] investigated different atomic-level morphologies of the $\mathrm{Cu}_{3} \mathrm{Pt}$ nanoparticles through chemical and electrochemical etching approaches, and showed that both etching processes led to improved electrocatalytic performances in the ORR compared with those of commercial Pt/C. Kwon and co-workers [15] also employed a chemical etching strategy to prepare dendrite-embedded Pt-Ni multiframes; the obtained Pt-Ni catalyst showed a marked enhancement in both mass and specific activity compared with the state of-the-art Pt/C cata- lyst.

Moreover, in order to achieve the large-scale production of catalysts enabling the practical application of PEMFCs, the fabrication process is required to be simple, scalable, and cost-effective. Many preparation methods have been developed so far, including polyol reduction, impregnation, electrochemical deposition, and magnetron sputtering [16-19]. Among these approaches, the polyol method was shown to be highly feasible and to offer advantages such as low-cost raw materials, high productivity, lower environmental pollution, mild reaction conditions, and simplified post-processing, which are beneficial for its industrial application [20]. However, the reducing capacity of polyol is insufficient for the alloying of Pt with transition metals, thus requiring the addition of a relatively strong reductant.

Herein, we have fabricated carbon-supported ultrafine Pt-Co nanoparticles through a facile and cost-effective modified glycol method, in which ethylene glycol not only acts as the solvent but also serves as the stabilizer (instead of a surfactant with high-molecular weight) to maintain the small size and homogeneous distribution the nanoparticles; moreover, the presence of excess sodium borohydride can effectively reduce the cobalt salts and contribute to the formation of the Pt-Co alloy. Thereafter, an acid etching strategy was employed in the washing process to remove the unstable Co atoms and rearrange the surface morphology and structure of the alloy, in order to further enhance its catalytic activity and stability. Following a modification of the above strategy, the resulting catalyst consisting of carbon-supported ultrafine platinum nanoparticles modified with trace amounts of Co was thoroughly characterized by physical methods. Electrochemical measurements further demonstrated that the as-prepared Pt-Co/C catalyst exhibits superior electrocatalytic activity and stability toward the ORR compared to those of commercial Pt/C, highlighting the potential of the catalyst to promote the widespread application of PEMFCs.

\section{Experimental}

\subsection{Materials}

Hexachloroplatinic acid hexahydrate $\left(\mathrm{H}_{2} \mathrm{PtCl}_{6} \cdot 6 \mathrm{H}_{2} \mathrm{O}\right)$ was purchased from Shenyang Research Institute of Nonferrous Metals. Cobalt(II) chloride hexahydrate $\left(\mathrm{CoCl}_{2} \cdot 6 \mathrm{H}_{2} \mathrm{O}\right)$, ethylene glycol (EG), sodium borohydride $\left(\mathrm{NaBH}_{4}\right)$, and sodium hydroxide $(\mathrm{NaOH})$ were obtained from Sinopharm Chemical Reagent Co., Ltd. Carbon black (Vulcan XC 72) was supplied by Cabot Corporation and Nafion was provided by Dupont. All chemicals were of analytical grade and used without further purification. Ultrapure deionized water was obtained from a Milli-Q Lab system and used for the preparation of all solutions.

\subsection{Preparation of carbon-supported ultrafine Pt-Co NPs}

Pt-Co/C catalysts with four different initial Pt/Co atom ratios $(4: 1,2: 1,1: 1,1: 2)$ were prepared by a one-pot method. A typical synthetic procedure is as follows: $50 \mathrm{mg}$ Vulcan XC-72 
was dispersed into $60 \mathrm{ml}$ EG by thoroughly stirring and ultrasonic blending for about $40 \mathrm{~min}$. Then, the dispersion was stirred at $60^{\circ} \mathrm{C}$ in an oil bath with intense flow of $\mathrm{N}_{2}$ for $30 \mathrm{~min}$. Subsequently, $40 \mathrm{mg}$ of $\mathrm{NaBH}_{4}$ was dissolved in a small amount of ultrapure deionized water and added dropwise to the suspension. Soon afterward, a solution containing $\mathrm{H}_{2} \mathrm{PtCl}_{6}$ and $\mathrm{CoCl}_{2}$ (consisting of a specific $\mathrm{CoCl}_{2}$ amount dissolved in $3 \mathrm{ml}$ water to achieve a total metal content of $20 \mathrm{wt} \%$ for the synthesis system) was added dropwise to the reaction mixture. After continuous stirring at $60^{\circ} \mathrm{C}$ for $30 \mathrm{~min}$, the alloying reaction was completed, and the Pt-Co/C catalysts were deposited by ultrasonic washing/centrifugation with ethanol and ultrapure water for several times. In order to release the unstable Co from the catalysts, an appropriate amount $\left(2 \mathrm{~mol} \mathrm{l}^{-1}\right)$ of nitric acid was added during every washing process, with the $\mathrm{pH}$ value of the cleaning solution kept at about 3. After drying under vacuum at $60^{\circ} \mathrm{C}$ for $12 \mathrm{~h}$, Pt-Co/C catalysts with trace amounts of Co were obtained.

\subsection{Physical characterization}

Transmission electron microscopy (TEM) measurements were carried out on a JEOL JEM-2000EX electron microscope operated at $120 \mathrm{kV}$. High-resolution TEM (HRTEM) images and energy dispersive X-ray spectroscopy (EDS) line scan profiles were obtained with a JEOL JEM-2100 transmission electron microscope operated at $200 \mathrm{kV}$. High-angle annular dark-field scanning TEM (HAADF-STEM) images and corresponding EDS mappings and line profiles were acquired on a JEM-ARM200F instrument (JEOL). Crystalline phase X-ray diffraction (XRD) patterns were obtained on a Rigaku D/MAX-2500/PC X-ray diffractometer using $\mathrm{Cu} K_{\alpha}$ radiation $(\lambda=0.154056 \mathrm{~nm})$. X-ray photoelectron spectroscopy (XPS) measurements were carried out using an ESCALAB 250Xi (Thermo Scientific) spectrometer with an $\mathrm{Al} K_{\alpha}$ radiation source. The composition of the as-synthesized catalysts was measured by inductively coupled plasma-atomic emission spectroscopy (ICP-AES, Perkin Elmer Optima 2000 DV).

\subsection{Electrochemical measurements}

Electrochemical measurements were conducted on a $\mathrm{CHI}$ 730D electrochemical station with a standard three-electrode cell at room temperature, using a glassy carbon disk electrode, Pt foil, and a saturated calomel electrode as working, counter, and reference electrodes, respectively. The electrolyte was a $\mathrm{HClO}_{4}$ aqueous solution $(0.1 \mathrm{~mol} / \mathrm{L})$ and all potentials were converted to the reversible hydrogen electrode (RHE) scale. The working electrode was prepared as follows: $5 \mathrm{mg}$ of catalysts were dispersed by ultrasonic sonication in a mixture containing $2.6 \mathrm{ml}$ isopropanol and $20 \mu \mathrm{l} 5 \mathrm{wt} \%$ Nafion. The suspension $(6 \mu \mathrm{l})$ was then pipetted on the glassy carbon disk and dried in natural air. Cyclic voltammetry (CV) curves were obtained in $\mathrm{N}_{2}$-saturated $0.1 \mathrm{~mol} / \mathrm{L} \mathrm{HClO}_{4}$ between 0.05 and $1.2 \mathrm{~V}$, with a scanning rate of $50 \mathrm{mV} \mathrm{s} \mathrm{s}^{-1}$. ORR polarization curves were recorded in $\mathrm{O}_{2}$-purged $0.1 \mathrm{~mol} / \mathrm{L} \mathrm{HClO}_{4}$ between 0.2 and $1.0 \mathrm{~V}$, with a sweep rate of $10 \mathrm{mV} \mathrm{s} \mathrm{s}^{-1}$ at $1600 \mathrm{rpm}$, and durabil- ity tests (ADTs) were performed between 0.6 and $1.2 \mathrm{~V}$ in $\mathrm{N}_{2}$-saturated $0.1 \mathrm{~mol} / \mathrm{L} \mathrm{HClO}_{4}$ at a scan rate of $50 \mathrm{mV} \mathrm{s}^{-1}$.

\subsection{PEMFC single-cell tests}

The catalyst ink was prepared by sonicating the mixture of catalyst, isopropanol, and $5 \mathrm{wt} \%$ Nafion described above. The cathode electrodes were prepared by coating the catalysts ink on the gas diffusion layer (GDL), and the Pt loadings measured by ICP were 73 and 98 ug $\mathrm{cm}^{-2}$ for the Pt-Co/C and Pt/C electrodes, respectively. The anode electrodes were commercial gas diffusion electrodes (GDEs) with a Pt loading of $0.3 \mathrm{mg}$ $\mathrm{cm}^{-2}$. Membrane electrode assemblies (MEAs) with a valuable area of $4 \mathrm{~cm}^{2}$ were prepared by sandwiching a Nafion 211 membrane (DuPont) between the cathode and anode electrodes, under a pressure of $0.2 \mathrm{MPa}$, at $140{ }^{\circ} \mathrm{C}$ for $2 \mathrm{~min}$. The single cells were then assembled by inserting the prepared MEAs between two graphite flow fields accompanied by metal end plates for the evaluation of the PEMFC performances.

An $850 \mathrm{E}$ single-cell test system was employed. The cells were operated at a temperature of $65^{\circ} \mathrm{C}$, with the cathode and anode fed with fully humidified air and hydrogen, respectively, and a backpressure of 1.5 bar on both sides. The cells were first activated under a series of current densities until the corresponding voltages were stable, and then $I-V$ curves were recorded by sweeping the current with a step of $50 \mathrm{~mA}$. Electrochemical impedance spectroscopy (EIS) measurements were then performed at a current density of $100 \mathrm{~mA} \mathrm{~cm}-2$, to obtain insight into the reaction kinetics of the electrodes.

$\mathrm{CV}$ curves were also recorded from 0.05 to $1.2 \mathrm{~V}$ with a scan rate of $50 \mathrm{mV} \mathrm{s}^{-1}$ at $30^{\circ} \mathrm{C}$, with the cathode and anode purged with nitrogen and hydrogen, respectively. ADTs were performed by scanning the potential between 0.6 and $1.2 \mathrm{~V}$ at a scan rate of $100 \mathrm{mV} \mathrm{s}^{-1}$. After the ADTs, we obtained CV, $I-V$, and EIS curves to further assess the PEMFC performance.

\section{Results and discussion}

\subsection{Composition, structure, and morphology characterization}

The elemental compositions of all catalysts were measured by ICP-AES and are listed in Table 1. The exact contents of Pt in the as-prepared Pt-Co/C catalysts are close to the nominal values, while the Co contents are much lower than the stoichiometric values, with residual concentrations of less than 4 at $\%$ in the catalysts. This phenomenon is probably due to the acid wash, as confirmed by previous studies on the leaching of

Table 1

Compositions of Pt-Co/C catalysts.

\begin{tabular}{lcccc}
\hline \multirow{2}{*}{ Catalyst } & \multirow{2}{*}{$\begin{array}{c}\text { Nominal Pt:M } \\
\text { ratio (atomic) }\end{array}$} & \multicolumn{3}{c}{ Composition from ICP analysis } \\
\cline { 3 - 5 } & - & Pt (wt\%) & Co (wt\%) & Pt:M (atomic) \\
\hline $\mathrm{Pt} / \mathrm{C}$ & $4: 1$ & 18.7 & - & - \\
$\mathrm{a}$ & $2: 1$ & 17.7 & 0.061 & $93: 1$ \\
$\mathrm{~b}$ & $1: 1$ & 15.6 & 0.131 & $82: 1$ \\
$\mathrm{c}$ & $1: 2$ & 13.2 & 0.129 & $36: 1$ \\
$\mathrm{~d}$ & & & & \\
\hline
\end{tabular}


non-precious metals [21-23]. The actual atomic ratios of Pt to Co for Pt-Co/C catalysts with initial Pt/Co atom ratios of 4:1, 2:1, 1:1, and $1: 2$, are 93:1, 82:1, 36:1, and 31:1, respectively. The actual atomic ratios will be used to refer to the $\mathrm{Pt}-\mathrm{Co} / \mathrm{C}$ catalysts in the following discussion.

To investigate the effect of the alloy composition on the crystalline structure, we measured the XRD patterns of the as-prepared Pt-Co/C catalysts, along with that of commercial $\mathrm{Pt} / \mathrm{C}$ for comparison. As shown in Fig. 1, the Pt-Co/C catalysts show typical Pt face-centered cubic (fcc) features. The broad peak located at $25^{\circ}$ is assigned to the $\mathrm{C}(002)$ plane of the $\mathrm{XC}-72$ carbon support, and the other four diffraction peaks at around $39.6^{\circ}, 46.3^{\circ}, 67.4^{\circ}$, and $81.4^{\circ}$ correspond to the Pt (111), Pt (200), Pt (220), and Pt (311) planes, respectively, consistent with the fcc Pt lattice [24]. As is well known, the Pt-Pt interatomic distance is larger than the Co-Co one; hence, the incorporation of Co into the Pt lattice would lead to compressive strain and a shorter Pt-Pt distance, which will be retained after the leaching of excess Co from the intermetallic [25]. As shown in the XRD pattern, the peak positions of the Pt lattice of the $\mathrm{Pt}-\mathrm{Co} / \mathrm{C}$ catalysts are shifted to higher angles relative to those of $\mathrm{Pt} / \mathrm{C}$, due to the shorter Pt-Pt distance; moreover, the shifts increase with increasing initial Co contents in the Pt-Co catalysts, demonstrating that the smaller Co atoms are effectively doped into the fcc crystal structure of Pt to produce an alloy phase $[26,27]$. On the other hand, no characteristic diffraction peaks of Co are detected in any of the Pt-Co/C samples, probably owing to the formation of the Pt-Co alloy.

The TEM images and corresponding particle size histograms of the as-synthesized Pt-Co/C catalysts and of commercial Pt/C are presented in Fig. 2. The Pt-Co nanoparticles with different $\mathrm{Pt} / \mathrm{Co}$ ratios exhibit approximately spherical shapes and are homogeneously dispersed over the entire surface of the carbon support, with a narrow size distribution. Moreover, the average particle sizes of the $\mathrm{Pt}_{93} \mathrm{Co} / \mathrm{C}, \mathrm{Pt}_{82} \mathrm{Co} / \mathrm{C}, \mathrm{Pt}_{36} \mathrm{Co} / \mathrm{C}$, and $\mathrm{Pt}_{31} \mathrm{Co} / \mathrm{C}$ catalysts are estimated to be $1.54,1.59,1.65$, and $1.46 \mathrm{~nm}$, respectively. On the other hand, commercial Pt/C exhibits a larger mean particle size, with a value of $2.21 \mathrm{~nm}$, which is about 1.4 times than the sizes of the Pt-Co NPs. These results indicate

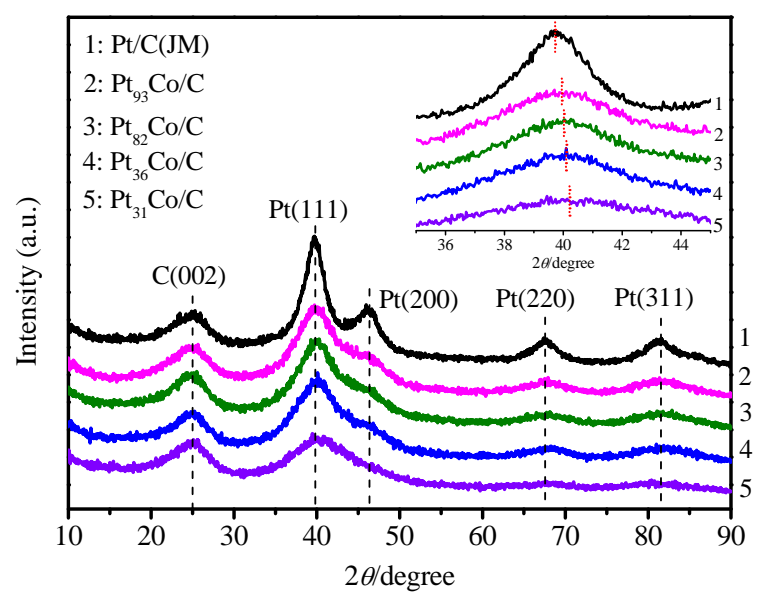

Fig. 1. XRD patterns of carbon-supported $\mathrm{Pt}$ and Pt-Co alloy catalysts. (1 Pt/C(JM); (2) Pt ${ }_{93} \mathrm{Co} / \mathrm{C}$; (3) $\mathrm{Pt}_{82} \mathrm{Co} / \mathrm{C}$; (4) $\mathrm{Pt}_{36} \mathrm{Co} / \mathrm{C}$; (5) $\mathrm{Pt}_{31} \mathrm{Co} / \mathrm{C}$.
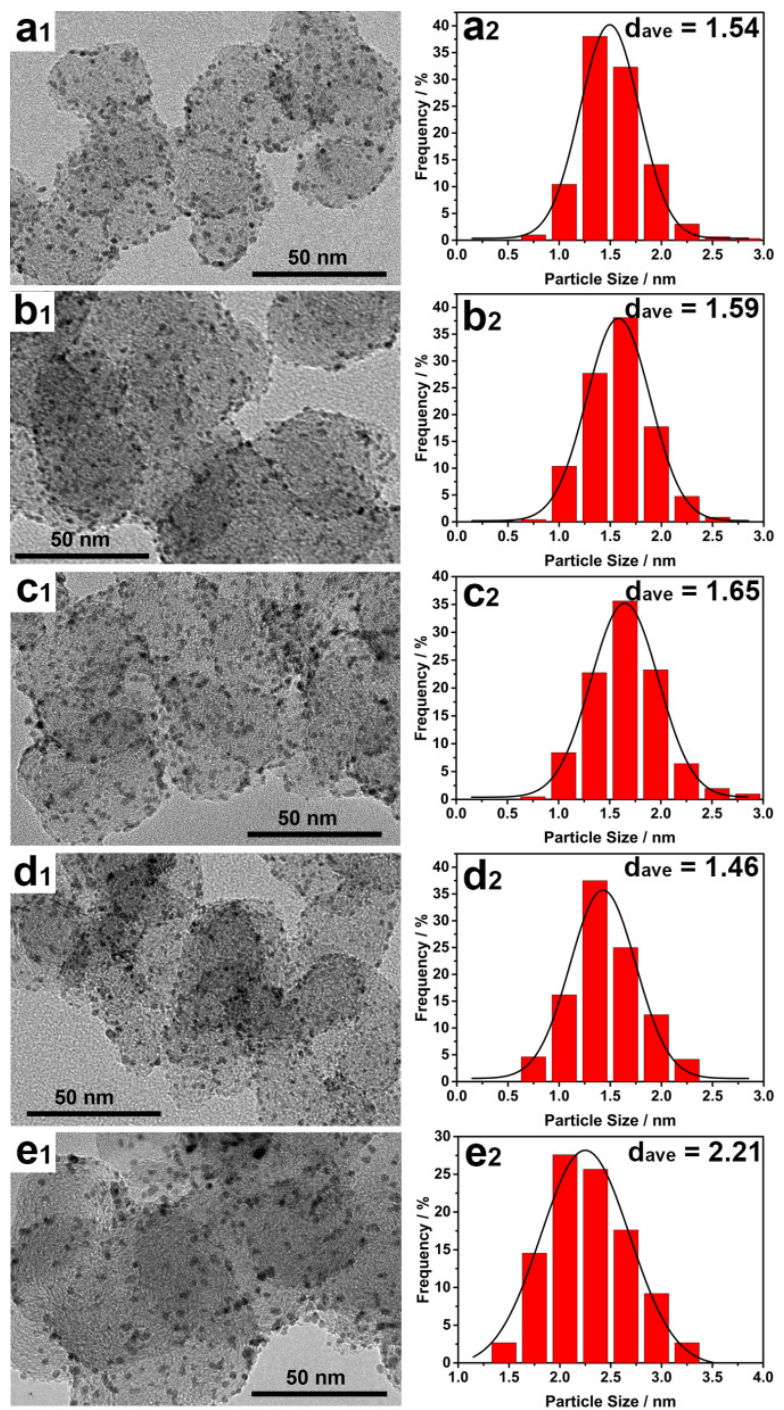

Fig. 2. Low-resolution TEM images and corresponding size distribution diagrams of $\mathrm{Pt}_{93} \mathrm{Co} / \mathrm{C}\left(\mathrm{a}_{1}, \mathrm{a}_{2}\right), \mathrm{Pt}_{82} \mathrm{Co} / \mathrm{C}\left(\mathrm{b}_{1}, \mathrm{~b}_{2}\right), \mathrm{Pt}_{36} \mathrm{Co} / \mathrm{C}\left(\mathrm{c}_{1}, \mathrm{c}_{2}\right)$, $\mathrm{Pt}_{31} \mathrm{Co} / \mathrm{C}\left(\mathrm{d}_{1}, \mathrm{~d}_{2}\right)$, and commercial Pt/C $\left(\mathrm{e}_{1}, \mathrm{e}_{2}\right)$.

that the particle size and distribution of the Pt-Co NPs can be well controlled in the synthesis process based on the modified EG method, without adding any other surfactants.

Furthermore, we performed a combined HRTEM/EDS analysis of $\mathrm{Pt}_{36} \mathrm{Co} / \mathrm{C}$ as a preliminary stage to investigate the fine morphology and elemental composition of the $\mathrm{Pt}-\mathrm{Co} / \mathrm{C}$ catalysts. The inset in Fig. 3(a) shows a well-defined fcc lattice with (111) and (200) crystalline facets, and the d-spacings of the corresponding lattice fringes decrease to 0.219 and $0.190 \mathrm{~nm}$, respectively, indicating that $\mathrm{Co}$ is successfully incorporated into the Pt crystal structure to form an alloy phase with a contracted lattice $[28,29]$. The selected-area electron diffraction (SAED) pattern of $\mathrm{Pt}_{36} \mathrm{Co} / \mathrm{C}$ exhibits a sets of concentric rings assigned to (111), (200), (220), and (311) reflections, which can also be indexed to the fcc crystal (Fig. 3(b)) [30]. In addition, the EDS spectrum also confirms the existence of a small amount of Co after the one-pot alloying and etching process, corroborating the XRD and HRTEM analyses discussed above (Fig. S1). More- 

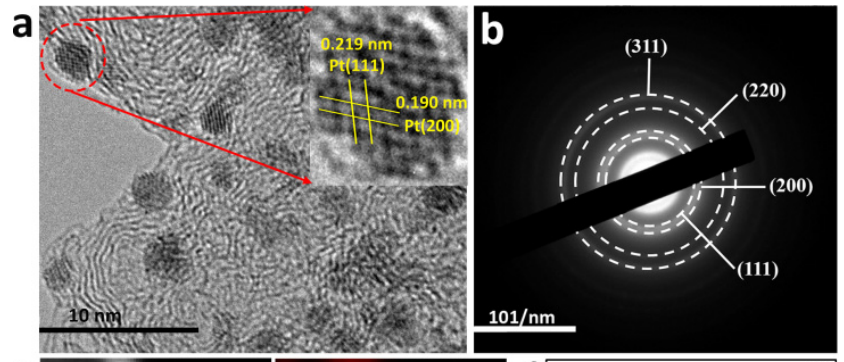

C
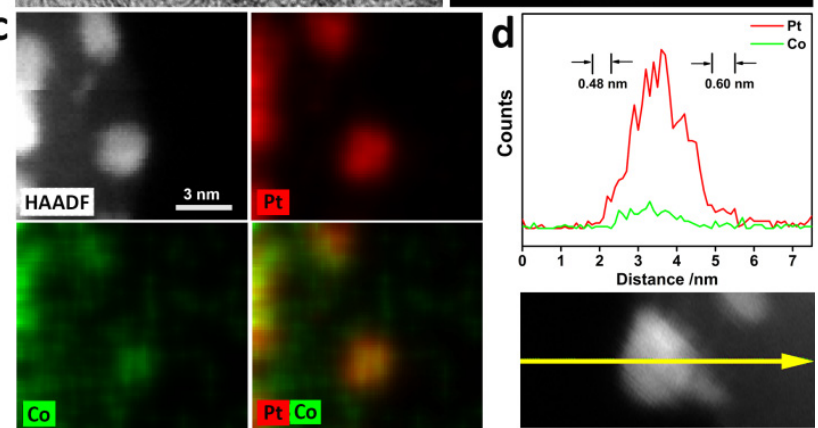

Fig. 3. Combined HRTEM-EDS analysis of $\mathrm{Pt}_{36} \mathrm{Co} / \mathrm{C}$ catalyst. (a) HRTEM image of $\mathrm{Pt}_{36} \mathrm{Co} / \mathrm{C}$; (b) SAED image of $\mathrm{Pt}_{36} \mathrm{Co} / \mathrm{C}$; (c) HAADF-STEM images of $\mathrm{Pt}_{36} \mathrm{Co} / \mathrm{C}$ and corresponding elemental maps of $\mathrm{Pt}$ (red) and Co (green), along with their overlap (Pt and Co); (d) EDS line scan profiles of $\mathrm{Pt}$ and $\mathrm{Co}$ extracted from a single $\mathrm{Pt}_{36} \mathrm{Co}$ nanoparticle.

over, the elemental distribution of $\mathrm{Pt}$ and Co within the $\mathrm{Pt}_{36} \mathrm{Co}$ nanoparticles was determined by HAADF-STEM and EDS mapping analyses. As shown in Fig. 3(c), both Pt and Co are distributed throughout the NPs, confirming the formation of the Pt-Co bimetallic alloy. To examine in higher detail the distribution of the atomic components in a $\mathrm{Pt}_{36}$ Co nanoparticle, EDS line scan profiles (marked with a yellow arrow) were obtained in
HAADF-STEM mode across a $\mathrm{Pt}_{36}$ Co NP. As illustrated in Fig. $3(d)$, both sides of the NP shows a region of low Co atomic concentration, measuring about 0.48 and $0.60 \mathrm{~nm}$ in length, which denotes the formation of Pt-rich shells [12]. This illustrates the effectiveness of the acid etching strategy in removing surface Co atoms and rearranging the surface structure of the alloy, which is expected to play an important role in retaining the inner bimetallic composition, leading to enhanced catalytic activity and stability $[31,32]$.

\subsection{Electrochemical performance}

$\mathrm{CV}$ and polarization curves were recorded to evaluate the ORR electrocatalytic activities of the as-prepared Pt-Co/C catalysts. For comparison, commercial $\mathrm{Pt} / \mathrm{C}$ was also examined under identical conditions. Prior to the electrochemical tests, the potential of the working electrode was scanned for several cycles between 0.05 and $1.2 \mathrm{~V}$ at $100 \mathrm{mV} \mathrm{s}^{-1}$ to activate the catalytic sites, and the obtained first activation curves are displayed in Fig. 4(a). Based on a previous study, the characteristic peak related to the oxidation of Co appears at $\sim 0.9 \mathrm{~V}$ [33]. However, no such peak is observed for $\mathrm{Pt}-\mathrm{Co} / \mathrm{C}$, indicating a limited dissolution of Co from the surfaces of the catalysts. The stabilized CV curves for all catalysts were recorded in a $\mathrm{N}_{2}$-saturated $0.1 \mathrm{~mol} / \mathrm{L} \mathrm{HClO}_{4}$ solution with a sweep rate of 50 $\mathrm{mV} \mathrm{s}^{-1}$ and are presented in Fig. 4(b). The peak pairs corresponding to the hydrogen adsorption/desorption on Pt are observed in the potential range of 0.03-0.4 V, characteristic of polycrystalline Pt. The specific electrochemical surface areas (ECSAs) were calculated from the following relation [34,35]:

$$
\mathrm{ECSA}=\frac{Q_{\mathrm{H}}}{0.21 *[\mathrm{Pt}]}
$$
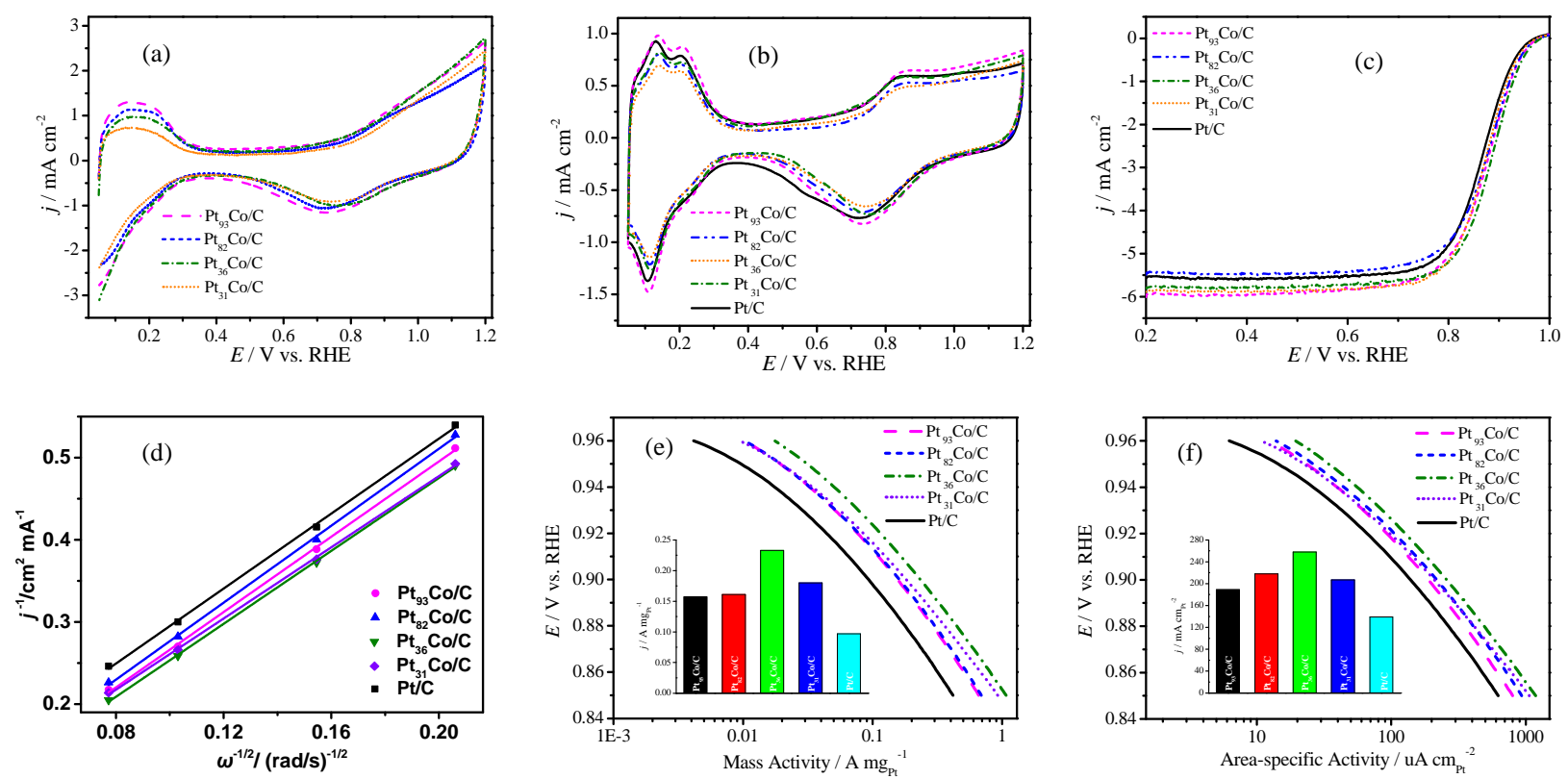

Fig. 4. (a) First activation curves of as-synthesized Pt-Co/C catalysts; (b) Stabilized CV curves of Pt-Co/C and commercial Pt/C catalysts; (c) ORR polarization curves of the catalysts in $\mathrm{O}_{2}$-saturated $0.1 \mathrm{~mol} / \mathrm{L} \mathrm{HClO}_{4}$ solution (The scanning rate $10 \mathrm{mV} \mathrm{s}{ }^{-1}$, rotation speed $1600 \mathrm{rpm}$ ); (d) $\mathrm{K}$ - $\mathrm{L}$ plots of all samples at the potential of $0.8 \mathrm{~V}$; (e, f) Mass and specific ORR activities expressed as kinetic current densities ( $j_{\mathrm{k}}$ ) normalized to the Pt mass and ECSA values of the catalvsts. resbectivelv. 
where $Q_{\mathrm{H}}$ is the Coulombic charge associated with hydrogen desorption $(\mathrm{mC}),[\mathrm{Pt}]$ represents the Pt loading $\left(\mathrm{mg}_{\mathrm{Pt}}\right)$, and the 0.21 value $\left(\mathrm{mC} \mathrm{cm}^{-2}\right)$ is the charge required to oxidize a monolayer of hydrogen on Pt sites. As shown in Table 2, the calculated ECSAs of $\mathrm{Pt}_{93} \mathrm{Co} / \mathrm{C}, \mathrm{Pt}_{82} \mathrm{Co} / \mathrm{C}, \mathrm{Pt}_{36} \mathrm{Co} / \mathrm{C}$, and $\mathrm{Pt}_{31} \mathrm{Co} / \mathrm{C}$ are 83.2, 73.8, 90.6, and $87.1 \mathrm{~m}^{2} \mathrm{~g}^{-1}$, respectively, which are obviously higher than the ECSA of commercial Pt/C $\left(69.7 \mathrm{~m}^{2} \mathrm{~g}^{-1}\right)$, implying that the utilization of Pt effectively increases in the $\mathrm{Pt}-\mathrm{Co} / \mathrm{C}$ catalysts. These results further confirm the small particle size and uniform dispersion of Pt nanoparticles controlled by the modified EG method, in agreement with the XRD and TEM results. Moreover, the higher ECSA values of the Pt-Co/C catalysts suggest that they are more electrochemically accessible compared to $\mathrm{Pt} / \mathrm{C}$; this feature could play an important role in enhancing the electrocatalytic kinetics of the ORR. The peak pairs observed in the potential range of 0.6-1.2 $\mathrm{V}$ correspond to the oxidation/reduction of Pt/Pt-0; among them, the peak potentials of $\mathrm{Pt}$ oxide reduction for the $\mathrm{Pt}-\mathrm{Co} / \mathrm{C}$ catalysts show a positive shift with respect to that of commercial Pt/C. This result shows that the adsorption of oxygenated species $\left(\mathrm{OH}_{\mathrm{ad}}\right)$ on the surface of the Pt sites is weaker for the Pt-Co/C catalysts, which would accelerate the ORR kinetics and lead to improved ORR catalytic activity [36].

Fig. 4(c) shows the ORR polarization curves of Pt-Co/C and commercial Pt/C catalysts measured in $\mathrm{O}_{2}$-saturated $0.1 \mathrm{~mol} / \mathrm{L}$ $\mathrm{HClO}_{4}$ solution at a sweep rate of $10 \mathrm{mV} \mathrm{s}^{-1}$. The electrocatalytic activity of the catalysts, as deduced from the half-wave potentials $\left(E_{1 / 2}\right)$, reaches its maximum for $\mathrm{Pt}_{36} \mathrm{Co} / \mathrm{C}$ and subsequently decreases for $\mathrm{Pt}_{82} \mathrm{Co} / \mathrm{C}, \mathrm{Pt}_{93} \mathrm{Co} / \mathrm{C}$, and $\mathrm{Pt}_{31} \mathrm{Co} / \mathrm{C}$, with values of 884, 877, 875, and $871 \mathrm{mV}$, respectively. All Pt-Co catalysts show positive shifts in $E_{1 / 2}$ compared to commercial Pt/C (867 $\mathrm{mV}$ ), indicating that the incorporation of Co could result in improved ORR activities. To further explore the catalytic kinetics process on the surface of the catalysts, the ORR polarization curves were measured at various rotation rates from 225 to 1600 rpm (Fig. S2). For a first-order reaction, the experimentally obtained current density $(j)$ shows a linear relation with the electrode rotation speed $(\omega)$ in the mixed control region, according to the Koutecky-Levich (K-L) equation [2]:

$$
\frac{1}{j}=\frac{1}{j_{k}}+\frac{1}{j_{d}}=\frac{1}{j_{k}}+\frac{1}{0.62 n F c D^{2 / 3} v^{-1 / 6} \omega^{1 / 2}}
$$

where $j_{k}$ is the kinetic current, $j_{d}$ is the diffusion-limiting current density, $n$ is the numbers of electrons transferred per oxygen molecule, $F$ is the Faraday constant (96485 $\mathrm{C} \mathrm{mol}^{-1}$ ), $c$ is the $\mathrm{O}_{2}$ concentration $\left(1.26 \times 10^{-6} \mathrm{~mol} \mathrm{~cm}^{-3}\right), D$ is the oxygen diffusion coefficient in the electrolyte $\left(1.9 \times 10^{-5} \mathrm{~cm}^{2} \mathrm{~s}^{-1}\right)$, and $v$ is

\section{Table 2}

Comparison of electrocatalytic activity toward ORR for Pt-Co/C catalysts and commercial Pt/C.

\begin{tabular}{lccccc}
\hline Catalyst & $\begin{array}{c}E_{1 / 2} \\
(\mathrm{mV})\end{array}$ & $\begin{array}{c}\mathrm{ECSA} \\
\left(\mathrm{m}^{2} \mathrm{~g}^{-1}\right)\end{array}$ & $\begin{array}{c}\text { SA at 0.9 V } \\
\left(\mu \mathrm{cm}^{-2}\right)\end{array}$ & $\begin{array}{c}\text { MA at 0.9 V } \\
\left(\mathrm{mA} \mathrm{mg}^{-1}\right)\end{array}$ & $n$ \\
\hline $\mathrm{Pt} / \mathrm{C}$ & 867 & 69.7 & 139 & 97 & 3.8 \\
$\mathrm{Pt}_{93} \mathrm{Co} / \mathrm{C}$ & 875 & 83.2 & 189 & 157 & 3.8 \\
$\mathrm{Pt}_{82} \mathrm{Co} / \mathrm{C}$ & 877 & 73.8 & 218 & 161 & 3.7 \\
$\mathrm{Pt}_{36} \mathrm{Co} / \mathrm{C}$ & 884 & 90.6 & 258 & 233 & 3.9 \\
$\mathrm{Pt}_{31} \mathrm{Co} / \mathrm{C}$ & 871 & 87.1 & 207 & 180 & 4.0 \\
\hline
\end{tabular}

the kinematic viscosity of the electrolyte solution $\left(1.009 \times 10^{-2}\right.$ $\mathrm{cm}^{2} \mathrm{~s}^{-1}$ ). The plots calculated at different potentials from 0.8 to $0.9 \mathrm{~V}$ on the basis of the Koutecky-Levich equation are displayed in Fig. 4(d), where the $j^{-1}$ value exhibits a good linear relationship with $\omega^{-1 / 2}$, implying that for all catalysts the ORR could be regarded as a first-order reaction. Moreover, the $n$ values obtained from the slopes of the plots are 3.8, 3.7, 3.9, and 4.0 for $\mathrm{Pt}_{93} \mathrm{Co} / \mathrm{C}, \mathrm{Pt}_{82} \mathrm{Co} / \mathrm{C}, \mathrm{Pt}_{36} \mathrm{Co} / \mathrm{C}$, and $\mathrm{Pt}_{31} \mathrm{Co} / \mathrm{C}$, respectively. These results demonstrate that the $\mathrm{Pt}-\mathrm{Co} / \mathrm{C}$ catalysts follows a four-electron transfer pathway, which is beneficial to improve the efficiency of the ORR [12]. To better understand the intrinsic electrocatalytic activities, the mass and specific activities (MA and SA, respectively) of the Pt-Co and commercial Pt/C catalysts were obtained by normalizing the kinetic currents $\left(j_{k}\right)$ to the Pt loadings and the ECSAs, respectively $[37,38]$. As illustrated in Fig. 4(e) and (f), the MAs and SAs of the Pt-Co catalysts show a clear improvement in the potential region ranging from 0.85 to $0.95 \mathrm{~V}$, compared with those of commercial Pt/C; the ORR activities of all catalysts at $0.9 \mathrm{~V}$ are listed in Table 2 . The results show that $\mathrm{Pt}_{36} \mathrm{Co} / \mathrm{C}$ possesses the highest mass activity among the Pt-Co/C catalysts, with a value of $233 \mathrm{~mA} \mathrm{mg}{ }^{-1}$, which is 2.4 times higher than that of commercial Pt/C $(97 \mathrm{~mA}$ $\mathrm{mg}^{-1}$ ). In addition, the Pt-Co/C catalysts show superior SAs compared to $\mathrm{Pt} / \mathrm{C}$; in particular, the SA of $\mathrm{Pt}_{36} \mathrm{Co} / \mathrm{C}(258 \mu \mathrm{A}$ $\mathrm{cm}^{-2}$ ) exhibits a $\sim 1$.9-fold increase relative to that of Pt/C (139 $\mu \mathrm{A} \mathrm{cm}-2$ ). The enhanced ORR activity of the Pt-Co/C materials could be attributed to both the larger ECSA and the accelerated electrocatalytic kinetics on the surface of the Pt-Co catalyst. To obtain further information on the ORR kinetics, the Tafel slopes, reflecting the resistance during the ORR process, were extracted from the polarization curves of $\mathrm{Pt}_{36} \mathrm{Co} / \mathrm{C}$ and $\mathrm{Pt} / \mathrm{C}$ [39]. In the low overpotential region ( $>0.8 \mathrm{~V}), \mathrm{Pt}_{36} \mathrm{Co} / \mathrm{C}$ shows a lower Tafel slope (89 $\mathrm{mV} \mathrm{dec}^{-1}$ ) compared with that of commercial Pt/C (93 mV dec ${ }^{-1}$ ), confirming that the $\mathrm{Pt}_{36} \mathrm{Co} / \mathrm{C}$ catalyst exhibits a more favorable ORR kinetics (Fig. S3) [39,40].

The stability is another important parameter for evaluating the performance of catalysts in PEMFCs. Herein, stability tests (ADTs) of $\mathrm{Pt}_{36} \mathrm{Co} / \mathrm{C}$ and commercial $\mathrm{Pt} / \mathrm{C}$ catalysts were performed in $0.1 \mathrm{~mol} / \mathrm{L} \mathrm{HClO}_{4}$ under $\mathrm{N}_{2}$ flow; the cycling potential range was selected to be $0.6-1.2 \mathrm{~V}$, as $0.6 \mathrm{~V}$ is the common working potential and $1.2 \mathrm{~V}$ would cause severe corrosion of the catalyst structures and accelerate the degradation process [4]. We investigated the changes in the ECSA and electrocatalytic activity of the catalysts. According to the CV measurements (Fig. 5(a) and (b)), $\mathrm{Pt}_{36} \mathrm{Co} / \mathrm{C}$ shows a $12 \%$ improvement in ECSA retention compared to that of commercial $\mathrm{Pt} / \mathrm{C}$, indicating that $\mathrm{Pt}_{36} \mathrm{Co} / \mathrm{C}$ possesses better durability than the $\mathrm{Pt} / \mathrm{C}$ catalyst. The linear sweep voltammetry (LSV) curves of $\mathrm{Pt}_{36} \mathrm{Co} / \mathrm{C}$ and $\mathrm{Pt} / \mathrm{C}$ after the ADTs were also recorded (Fig. $5(c)$ ), and the corresponding calculated mass activities are shown in Fig. 5(d). The figure reveals that the retention of mass activity for $\mathrm{Pt}_{36} \mathrm{Co} / \mathrm{C}$ is competitive to that of commercial $\mathrm{Pt} / \mathrm{C}$, while the retained mass activity of $\mathrm{Pt}_{36} \mathrm{Co} / \mathrm{C}$ after the ADT remains greater than that of pristine commercial Pt/C. To confirm the enhanced durability, we performed a TEM analysis of $\mathrm{Pt}_{36} \mathrm{Co} / \mathrm{C}$ and $\mathrm{Pt} / \mathrm{C}$ after the ADT, which revealed lower agglomeration and sintering of $\mathrm{Pt}$ atoms for $\mathrm{Pt}_{36} \mathrm{Co} / \mathrm{C}$ than com- 

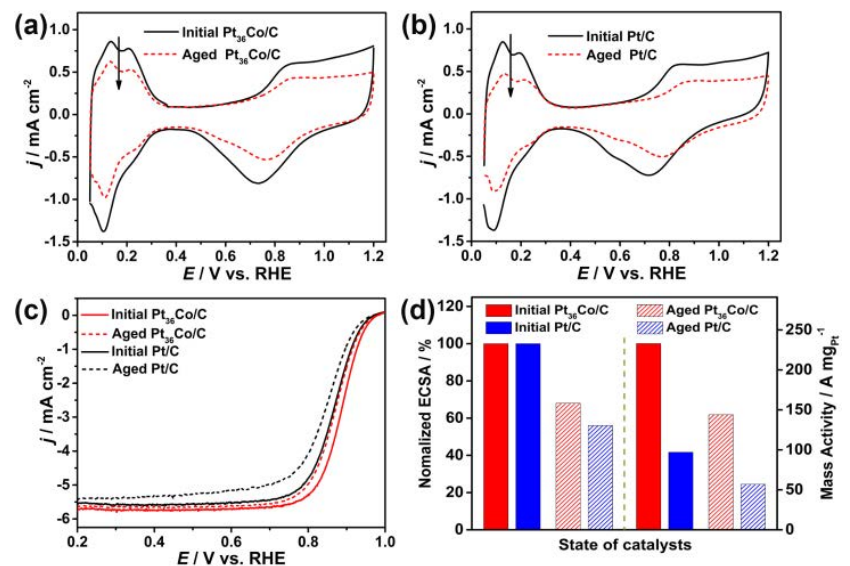

Fig. 5. CV curves for $\mathrm{Pt}_{36} \mathrm{Co} / \mathrm{C}$ catalyst (a) and commercial $\mathrm{Pt} / \mathrm{C}$ (b) before and after 1500 cycles in $\mathrm{N}_{2}$-saturated $0.1 \mathrm{~mol} / \mathrm{L} \mathrm{HClO}_{4}$ solution at room temperature with a sweep rate of $50 \mathrm{mV} \mathrm{s}^{-1}$; (c) Comparison of ORR activities of $\mathrm{Pt}_{36} \mathrm{Co} / \mathrm{C}$ and $\mathrm{Pt} / \mathrm{C}$ before and after 1500 electrochemical cycles; (d) Comparison of ECSA and mass activities of $\mathrm{Pt}_{36} \mathrm{Co} / \mathrm{C}$ and $\mathrm{Pt} / \mathrm{C}$ before and after 1500 electrochemical cycles.

mercial Pt/C (Fig. S4). This result is consistent with a previous work, which ascribed it to an anchoring effect, in which the migration of $\mathrm{Pt}$ on carbon is restrained in the presence of Co [41].

\subsection{PEMFC single-cell tests}

As the $\mathrm{Pt}_{36} \mathrm{Co} / \mathrm{C}$ catalyst exhibits superior electrocatalytic performance in half-cell tests, it was further evaluated in a single-cell system, which is closer to the real PEMFC conditions, and the test results were compared to those of commercial $\mathrm{Pt} / \mathrm{C}$.

Fig. 6(a) displays the single-cell structure. The $I-V$ curves of electrodes based on $\mathrm{Pt}_{36} \mathrm{Co} / \mathrm{C}$ and commercial $\mathrm{Pt} / \mathrm{C}$ cathodes are shown in Fig. 6(b). The figure shows that the peak power density of the $\mathrm{Pt}_{36} \mathrm{Co} / \mathrm{C}$-based electrode is $0.750 \mathrm{~W} \mathrm{~cm}^{-2}$, which represents an obvious improvement compared to that of the conventional $\mathrm{Pt} / \mathrm{C}$ one $\left(0.624 \mathrm{~W} \mathrm{~cm}^{-2}\right)$. The Pt loadings for the

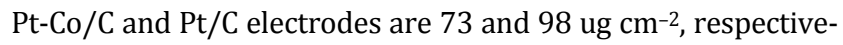
ly (Table 3 ). For a better comparison, the $I-V$ curves were normalized to the Pt loadings. The maximum mass-specific power density obtained for the $\mathrm{Pt}_{36} \mathrm{Co} / \mathrm{C}$-based electrode is $10.27 \mathrm{~W}$ $\mathrm{mgP}^{-1}$, which is 1.61 times higher than the value of the conventional Pt/C electrode (6.37 $\mathrm{W} \mathrm{mgte}^{-1}$, Fig. 6(c)), and is competitive with the results of state-of-the-art Pt-based PEMFCs (Table 4). To obtain insight into the cell performance, EIS and CV tests were conducted during the performance evaluation. In particular, we performed EIS measurements at a current density of $100 \mathrm{~mA} \mathrm{~cm}^{-2}$ to further understand the electrode kinetics [42]. As shown in Fig. 6(d), the diameter of the semicircle corresponds to $R_{\mathrm{ct}}$, which represents the activation resistance towards the ORR [43]. The $R_{\mathrm{ct}}$ of the $\mathrm{Pt}_{36} \mathrm{Co} / \mathrm{C}$-based electrode $\left(0.53 \Omega \mathrm{cm}^{2}\right)$ is smaller than that of the Pt/C-based electrode $\left(0.65 \Omega \mathrm{cm}^{2}\right)$; this implies that the intrinsic activity of $\mathrm{Pt}_{36} \mathrm{Co} / \mathrm{C}$ is higher than that of Pt/C. Apart from the intrinsic activity, the electrochemical activity is also positively correlated with the
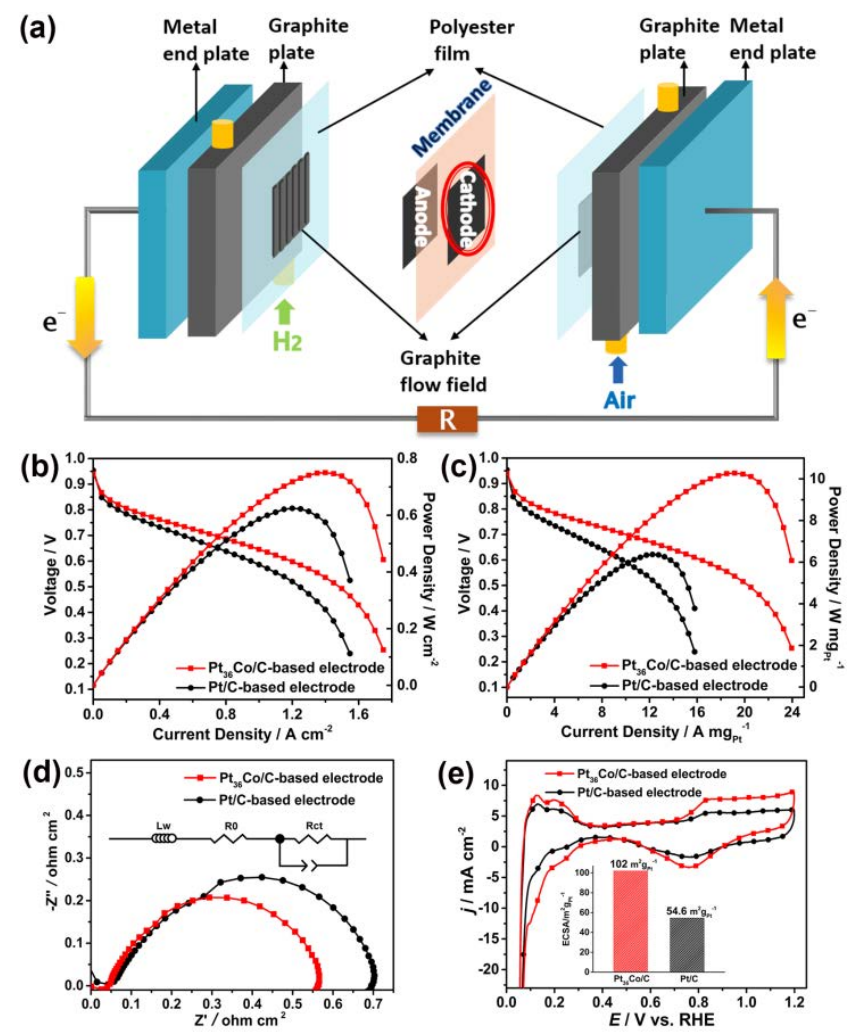

Fig. 6. PEMFC single-cell tests. (a) Structural representation of a single cell; (b) $I-V$ curves of electrodes based on $\mathrm{Pt}_{36} \mathrm{Co} / \mathrm{C}$ and commercial $\mathrm{Pt} / \mathrm{C}$ cathodes; (c) $\mathrm{I}-V$ curves with current density normalized to the $\mathrm{Pt}$ loadings for electrodes based on $\mathrm{Pt}_{36} \mathrm{Co} / \mathrm{C}$ and commercial $\mathrm{Pt} / \mathrm{C}$ cathodes; (d) EIS measurements recorded at a current density of $100 \mathrm{~mA}$ $\mathrm{cm}^{-2}$ for electrodes based on $\mathrm{Pt}_{36} \mathrm{Co} / \mathrm{C}$ and commercial $\mathrm{Pt} / \mathrm{C}$ cathodes; (e) CV curves of electrodes based on $\mathrm{Pt}_{36} \mathrm{Co} / \mathrm{C}$ and commercial $\mathrm{Pt} / \mathrm{C}$ cathodes.

number of available active sites, i.e., with the ECSA $[44,45]$. As shown in Fig. 6(e), the ECSA of the conventional Pt/C electrode measured in the hydrogen desorption region is $54.6 \mathrm{~m}^{2} \mathrm{gPt}^{-1}$, while the $\mathrm{Pt}_{36} \mathrm{Co} / \mathrm{C}$-based electrode shows a higher value of $102.0 \mathrm{~m}^{2} \mathrm{gPt}^{-1}$. The much larger ECSA of the latter electrode is mainly attributed to the ultrasmall size of the active Pt-Co NPs, which in turn may contribute to the enhanced ORR activity.

The durability of the electrodes was investigated by ADTs in the scanning potential region of 0.6-1.2 V. As shown in Fig. 7(a)-(c), during 3000 cycling scans, the ECSA of $\mathrm{Pt}_{36} \mathrm{Co} / \mathrm{C}$-based electrode shows a smaller decrease compared to that of the conventional $\mathrm{Pt} / \mathrm{C}$ one, and finally retains $47 \%$ of its initial value, which is competitive with that of the $\mathrm{Pt} / \mathrm{C}$ electrode $(33 \%)$. Moreover, the decrease in peak power density for the $\mathrm{Pt}_{36} \mathrm{Co} / \mathrm{C}$-based electrode after the ADTs is measured to be

Table 3

Characteristic parameters of electrodes used as cathode in single-cell tests.

\begin{tabular}{|c|c|c|c|c|c|}
\hline \multirow{2}{*}{ Electrode } & \multirow{2}{*}{$\begin{array}{l}\text { Pt loading } \\
\left(\mu \mathrm{g} \mathrm{cm}^{-2}\right)\end{array}$} & \multicolumn{2}{|c|}{ Power density } & \multirow{2}{*}{$\begin{array}{c}R_{\mathrm{ct}} \\
\left(\Omega \mathrm{cm}^{2}\right)\end{array}$} & \multirow{2}{*}{$\begin{array}{c}\text { ECSA } \\
\left(\mathrm{m}^{2} \mathrm{~g}_{\mathrm{pt}^{-1}}\right.\end{array}$} \\
\hline & & $\left(\mathrm{W} \mathrm{cm}^{-2}\right)$ & $\left(\mathrm{W} \mathrm{mg}_{\mathrm{Pt}^{-1}}\right)$ & & \\
\hline & 73 & 0.7 & 10 & 0.5 & 102.0 \\
\hline Pt/C-based & 98 & 0.624 & 6.37 & 0.65 & 54.6 \\
\hline
\end{tabular}


Table 4

Comparison of PEMFC performance of $\mathrm{Pt}_{36} \mathrm{Co} / \mathrm{C}$ and state-of-the-art Pt-based architectures.

\begin{tabular}{|c|c|c|c|c|c|c|}
\hline Electrode & Atmosphere & $\begin{array}{c}\text { Temperature } \\
\left({ }^{\circ} \mathrm{C}\right) \\
\end{array}$ & $\begin{array}{l}\text { Pt loading } \\
\left(\mathrm{mg} \mathrm{cm}^{-2}\right)\end{array}$ & $\begin{array}{c}\text { Peak power density } \\
\left(\mathrm{W} \mathrm{cm}^{-2}\right)\end{array}$ & $\begin{array}{l}\text { Maximum mass power } \\
\text { density }\left(\mathrm{W} \mathrm{mg}_{\mathrm{Pt}^{-1}}{ }^{-1}\right)\end{array}$ & Ref. \\
\hline $\mathrm{Pt}_{36} \mathrm{Co} / \mathrm{C}$ & $\mathrm{H}_{2} /$ air & 65 & 0.073 & 0.75 & 10.27 & This work \\
\hline $\mathrm{PtCo} / \mathrm{CCCS}$ & $\mathrm{H}_{2} /$ air & 80 & 0.1 & 0.603 & 6.03 & [35] \\
\hline AL-PtCo/CN & $\mathrm{H}_{2} /$ air & 80 & 0.1 & $\sim 0.5$ & $\sim 5$ & {$[46]$} \\
\hline Pt-Co NWs/C & $\mathrm{H}_{2} /$ air & 80 & $\sim 0.36$ & $\sim 0.725$ & 2.01 & [47] \\
\hline $\mathrm{PtCoFe} / \mathrm{SG}$ & $\mathrm{H}_{2 /} \mathrm{O}_{2}$ & 75 & 0.1 & 0.530 & 5.3 & [48] \\
\hline PtPdND & $\mathrm{H}_{2} /$ air & 70 & $\sim 0.39$ & 0.73 & $<1.9$ & [49] \\
\hline $\mathrm{PtCu} / \mathrm{CNT}$ & $\mathrm{H}_{2} / \mathrm{O}_{2}$ & 60 & 0.5 & 0.452 & 0.9 & [50] \\
\hline PtHS & $\mathrm{H}_{2} /$ air & 80 & 0.55 & $\sim 0.55$ & $\sim 1.0$ & {$[51]$} \\
\hline Pt-PANI & $\mathrm{H}_{2} / \mathrm{O}_{2}$ & 70 & 0.095 & 0.542 & 5.7 & [52] \\
\hline PtTiO2@PANI & $\mathrm{H}_{2} / \mathrm{O}_{2}$ & 70 & 0.2 & 0.774 & 3.87 & [53] \\
\hline $\mathrm{Pt} / \mathrm{TOMS}$ & $\mathrm{H}_{2} / \mathrm{O}_{2}$ & 80 & 0.2 & 0.973 & 4.87 & {$[54]$} \\
\hline Pt/SWCNT & $\mathrm{H}_{2} / \mathrm{O}_{2}$ & $50-55$ & 0.5 & 0.365 & 0.73 & [55] \\
\hline
\end{tabular}

$23 \%$, which is clearly lower than that of the conventional Pt/C electrode (33\%) (Fig. 7(d) and (e)). In addition, to gain further insight into the performance degradation, we also examined the changes in the EIS data. As shown in Fig. 7(f), the $R_{\mathrm{ct}}$ at 100 $\mathrm{mA} \mathrm{cm}-2$ for the $\mathrm{Pt}_{36} \mathrm{Co} / \mathrm{C}$-based electrode increases by $38 \%$ after the ADTs, while the value of the Pt/C electrode increases by $50 \%$. The smaller $R_{\mathrm{ct}}$ increase implies a lower decrease of ORR activity for $\mathrm{Pt}_{36} \mathrm{Co} / \mathrm{C}$ than $\mathrm{Pt} / \mathrm{C}$. This is in agreement with the $\mathrm{CV}$ and $I-V$ data, demonstrating the improved electrochemical durability of the $\mathrm{Pt}_{36} \mathrm{Co} / \mathrm{C}$ electrode.

In general, the $\mathrm{Pt}_{36} \mathrm{Co} / \mathrm{C}$-based electrode exhibits superior activity and enhanced durability under single-cell working conditions, highlighting its great potential for practical PEMFC applications.

\subsection{XPS analysis}

XPS measurements were performed to further investigate the enhancing effect of Co doping on the ORR for PEMFC applications. As shown in Fig. 8, the Pt $4 f$ peaks of the $\mathrm{Pt}_{36} \mathrm{Co} / \mathrm{C}$ catalyst shift to higher binding energies (BEs) compared to those of $\mathrm{Pt} / \mathrm{C}$, with a value of $0.26 \mathrm{eV}$ (Fig. 8(a)). The positive shift in the BEs of Pt can be ascribed to the electronic interaction between $\mathrm{Pt}$ and $\mathrm{Co}$ and the compressive strain induced by Co, decreasing the Pt-Pt interatomic distance [26,56]. As is well known, the chemical interaction between oxygen species and Pt is influenced by the d-band center, which determines the ORR specific activity $[31,57]$. The positively shifted BEs of Pt would reduce the adsorption of oxygenated species on the catalytic surface
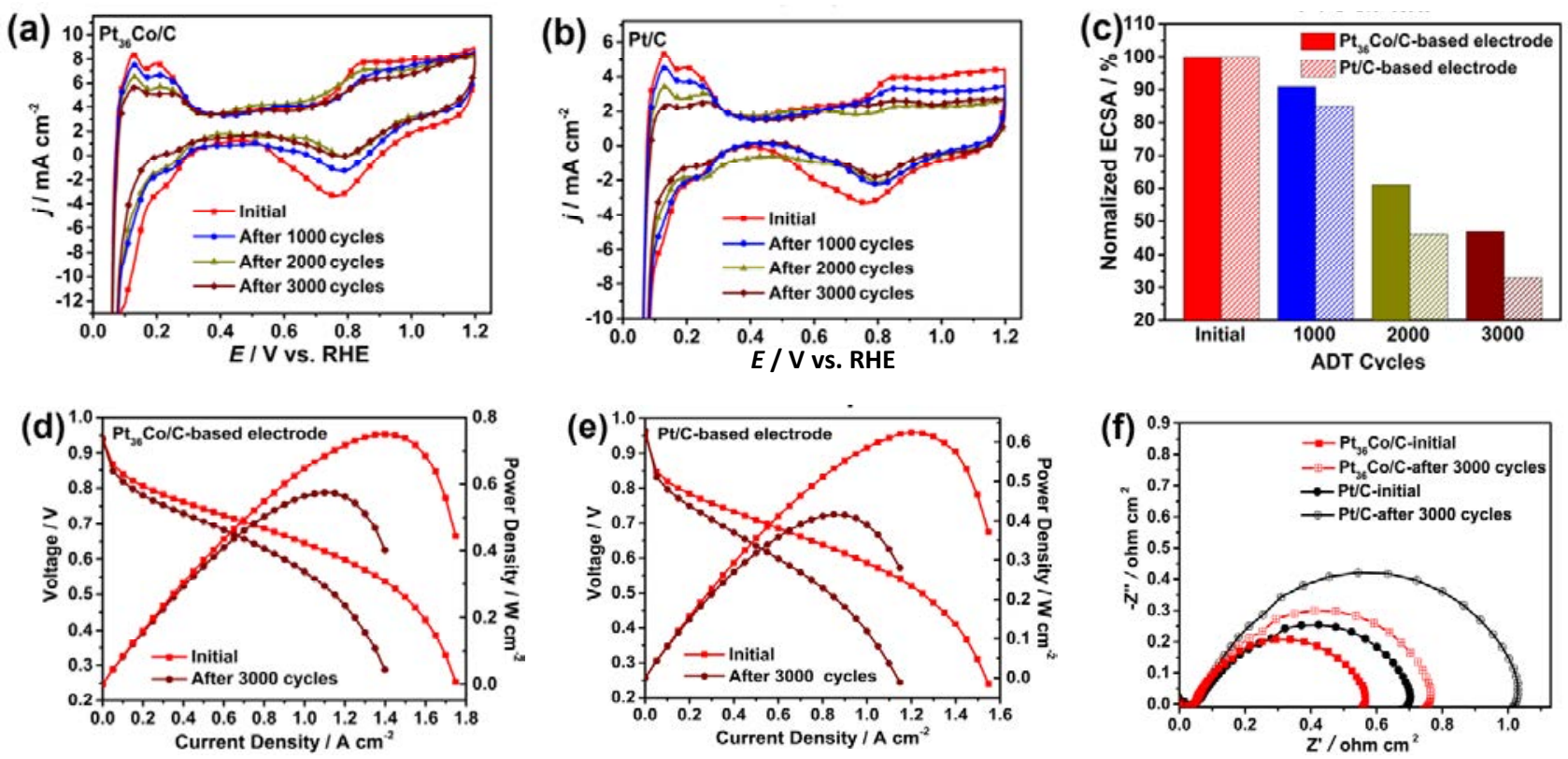

Fig. 7. (a,b) CV curves of $\mathrm{Pt}_{36} \mathrm{Co} / \mathrm{C}$ - and $\mathrm{Pt} / \mathrm{C}$-based electrodes recorded during the ADTs; (c) ECSA retention of $\mathrm{Pt}{ }_{36} \mathrm{Co} / \mathrm{C}$ - and $\mathrm{Pt} / \mathrm{C}$-based electrodes during the ADTs; (d,e) I-V curves of $\mathrm{Pt}_{36} \mathrm{Co} / \mathrm{C}$ - and Pt/C-based electrodes recorded before and after the ADTs; (f) EIS plots of Pt ${ }_{36} \mathrm{Co} / \mathrm{C}$ - and Pt/C-based electrodes recorded at a current density of $100 \mathrm{~mA} \mathrm{~cm}^{-2}$ before and after the ADTs. 

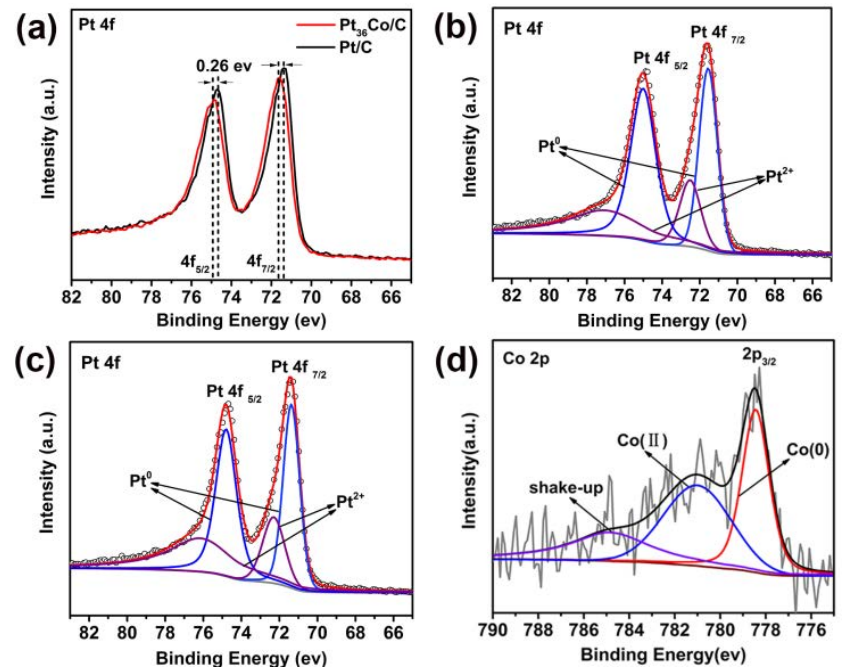

Fig. 8. XPS analysis: (a) BE shift of $\mathrm{Pt} 4 f$ spectra for $\mathrm{Pt}_{36} \mathrm{Co}$ and $\mathrm{Pt} / \mathrm{C}$ electrocatalysts; high-resolution $\mathrm{Pt} 4 f$ spectra of $\mathrm{Pt}_{36} \mathrm{Co}(\mathrm{b})$ and $\mathrm{Pt} / \mathrm{C}$ (c); (d) high-resolution Co $2 p$ spectra of $\mathrm{Pt}_{36} \mathrm{Co} / \mathrm{C}$ electrocatalyst.

and thus accelerate the electrocatalytic ORR kinetics; moreover, the dissolution of Pt atoms via the formation of Pt-O bonds would also be hindered [58]. The high-resolution Pt $4 f$ peaks of $\mathrm{Pt}_{36} \mathrm{Co} / \mathrm{C}$ and $\mathrm{Pt} / \mathrm{C}$ can be deconvoluted into two pairs of doublets (Fig. 8(b) and (c)). In the case of $\mathrm{Pt}_{36} \mathrm{Co} / \mathrm{C}$, the most intense doublet observed at $71.58\left(\mathrm{Pt} 4 f_{5 / 2}\right)$ and $75.01 \mathrm{eV}(\mathrm{Pt}$ $\left.4 f_{7 / 2}\right)$ is assigned to metallic $\operatorname{Pt}(0)$, while the weaker doublet at 72.61 and $77.09 \mathrm{eV}$ can be attributed to Pt(II) species such as $\mathrm{PtO}$ or $\mathrm{Pt}(\mathrm{OH})_{2}$, indicating some surface oxidation. The BEs and corresponding intensities of the $\mathrm{Pt} 4 f$ spectra for $\mathrm{Pt}_{36} \mathrm{Co} / \mathrm{C}$ and $\mathrm{Pt} / \mathrm{C}$ catalysts are displayed in Table 5, which shows that $\mathrm{Pt}_{36} \mathrm{Co} / \mathrm{C}$ possesses a higher metallic $\mathrm{Pt}(0)$ content $(65.3 \%)$ than Pt/C (59.2\%). This result is probably due to the change in electronic structure, which is consistent with previous results showing that alloying Pt with Co can effectively reduce the oxophilicity of Pt $[33,59]$. The larger percentage of $\operatorname{Pt}(0)$ species could supply more free Pt sites available for the adsorption/desorption of $\mathrm{O}_{2}$ during the ORR process, thus contributing to the enhanced ORR activity [32]. In addition, the XPS spectrum of Co was also analyzed and is displayed in Fig. 8(d). The high-resolution Co $2 p_{3 / 2}$ spectrum can be fitted by three peaks at 778.5, 781.0, and $784.8 \mathrm{eV}$, corresponding to metallic $\mathrm{Co}(0), \mathrm{Co}(\mathrm{II})$ species such as $\mathrm{CoO}$, and shake-up peaks indexed to high-spin Co(II) species, respectively. Notably, the peak of Co $2 p$ in the metallic state also shows a positive shifts to higher BEs compared to that of bulk Co $(778.3 \mathrm{eV})$, confirming the

\section{Table 5}

BEs and relative intensities of different platinum species observed in high-resolution $\mathrm{Pt} 4 f$ spectra of $\mathrm{Pt}_{36} \mathrm{Co}$ and $\mathrm{Pt} / \mathrm{C}$ electrocatalysts.

\begin{tabular}{lcccc}
\hline Catalyst & $\begin{array}{c}\text { Chemical } \\
\text { state }\end{array}$ & $\begin{array}{c}\mathrm{Pt} 4 f_{7 / 2} \mathrm{BE} \\
(\mathrm{eV})\end{array}$ & $\begin{array}{c}\mathrm{Pt} 4 f_{5 / 2} \mathrm{BE} \\
(\mathrm{eV})\end{array}$ & $\begin{array}{c}\text { Relative intensity } \\
(\%)\end{array}$ \\
\hline $\mathrm{Pt}_{36} \mathrm{Co} / \mathrm{C}$ & $\mathrm{Pt}(0)$ & 71.58 & 75.01 & 65.3 \\
& $\mathrm{Pt}(\mathrm{II})$ & 72.61 & 77.09 & 34.7 \\
$\mathrm{Pt} / \mathrm{C}$ & $\mathrm{Pt}(0)$ & 71.37 & 74.80 & 59.2 \\
& $\mathrm{Pt}(\mathrm{II})$ & 72.31 & 76.12 & 40.8 \\
\hline
\end{tabular}

charge transfer from Co to Pt [33].

\section{Conclusions}

In summary, we have reported a facile and cost-effective method to rationally fabricate carbon black-decorated Pt-Co bimetallic nanoparticles ( $\mathrm{Pt}-\mathrm{Co} / \mathrm{C}$ ), in which an ultrasmall size and a homogeneous distribution of the Pt-Co NPs were obtained without the addition of an extra surfactant. Moreover, an acid etching approach was employed to remove unstable Co atoms and rearrange the surface morphology and structure of the bimetallic NPs, thus further enhancing the catalytic activity and stability. The resulting catalyst, consisting of carbon-supported ultrafine platinum nanoparticles modified with trace amounts of Co, was thoroughly characterized by physical methods. Electrochemical measurements further reveal that the as-synthesized Pt-Co/C catalyst exhibits a significantly enhanced electrocatalytic activity and stability in the ORR when applied as cathode of PEMFCs, compared with those of commercial Pt/C. This result is mainly attributed to the modification of the surface electronic properties induced by the incorporation of Co, which was also confirmed by XPS analysis. Overall, the enhanced ORR electrocatalysts developed by a low-cost route would not only support the widespread application of PEMFCs, but also provide a new pathway for their use in other catalysis and energy fields.

\section{References}

[1] M. Kiani, J. Zhang, Y. Luo, C. Jiang, J. Fan, G. Wang, J. Chen, R. Wang, J. Energy Chem., 2018, 27, 1124-1139.

[2] A. Ghosh, P. Chandran, S. Ramaprabhu, Appl. Energy, 2017, 208, 37-48.

[3] Y. Deng, H. Huangfu, S. Tang, J. Li, Chin. J. Catal., 2017, 38, 1668-1679.

[4] X. Tang, Y. Zeng, L. Cao, L. Yang, Z. Wang, D. Fang, Y. Gao, Z. Shao, B. Yi, J. Mater. Chem. A, 2018, 6, 15074-15082.

[5] J. Y. Wang, X. Mu, Y. Li, F. Xu, J. Chen, L. Ouyang, H. Liu, Y. Jing, H. Dai, C. Liu, X. D. Zhang, W. Long, P. Bian, J. Wang, Y. Sun, J. Yang, Small, 2018, 14, e1703736.

[6] G. Zhang, W. Lu, L. Cao, X. Qin, F. Ding, S. Tang, Z. G. Shao, B. Yi, J. Power Sources, 2016, 326, 23-34.

[7] W. Gu, J. Liu, M. Hu, F. Wang, Y. Song, ACS Appl. Mater. Interfaces, 2015, 7, 26914-26922.

[8] M. Shao, Q. Chang, J. P. Dodelet, R. Chenitz, Chem. Rev., 2016, 116, 3594-3657.

[9] J. Choi, J. H. Jang, C. W. Roh, S. Yang, J. Kim, J. Lim, S.J. Yoo, H. Lee, Appl. Catal. B, 2018, 225, 530-537.

[10] Y. Kim, H. Lee, T. Lim, H. J. Kim, O. J. Kwon, J. Power Sources, 2017, $364,16-22$.

[11] X. Huang, Z. Zhao, L. Cao, Y. Chen, E. Zhu, Z. Lin, M. Li, A. Yan, A. Zettl, Y. M. Wang, X. Duan, T. Mueller, Y. Huang, Science, 2015, 348, 1230-1234.

[12] D. S. Choi, A. W. Robertson, J. H. Warner, S. O. Kim, H. Kim, Adv. Mater., 2016, 28, 7115-7122.

[13] J. H. Dumont, A. M. Baker, S. Maurya, Y. S. Kim, R. Mukundan, D. J. Myers, R. L. Borup, ECS Trnas., 2017, 80, 861-867.

[14] D. Wang, Y. Yu, J. Zhu, S. Liu, D. A. Muller, H. D. Abruna, Nano Lett., 2015, 15, 1343-1348. 


\section{Graphical Abstract}

Chin. J. Catal., 2019, 40: 504-514 doi: S1872-2067(19)63304-8

Carbon-supported ultrafine Pt nanoparticles modified with trace amounts of cobalt as enhanced oxygen reduction reaction catalysts for proton exchange membrane fuel cells

Xuejun Tang, Dahui Fang, Lijuan Qu, Dongyan Xu, Xiaoping Qin, Bowen Qin, Wei Song, Zhigang Shao*, Baolian Yi Dalian Institute of Chemical Physics, Chinese Academy of Sciences; University of Chinese Academy of Sciences; Qingdao University of Science and Technology
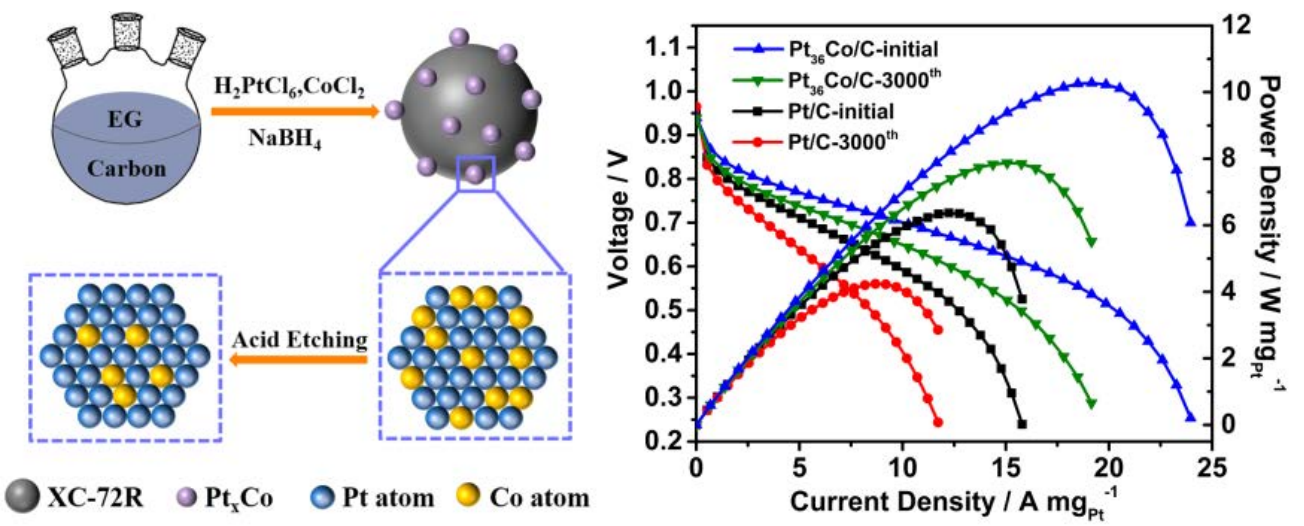

Carbon-supported ultrafine Pt nanoparticles modified with trace cobalt were fabricated through a strategy involving modified glycol reduction and chemical etching. The obtained $\mathrm{Pt}_{36} \mathrm{Co} / \mathrm{C}$ catalyst possessed a significantly enhanced power density compared to that of conventional Pt/C.

[15] H. Kwon, M. K. Kabiraz, J. Park, A. Oh, H. Baik, S. I. Choi, K. Lee, Nano Lett., 2018, 18, 2930-2936.

[16] D. J. You, D. H. Kim, J. R. De Lile, C. Li, S. G. Lee, J. M. Kim, C. Pak, Appl. Catal. A, 2018, 562, 250-257.

[17] L. Lei, Z. Tao, T. Hong, X. Wang, F. Chen, J. Power Sources, 2018, $389,1-7$.

[18] D. Dang, L. Zhang, X. Zeng, X. Tian, C. Qu, H. Nan, T. Shu, S. Hou, L. Yang, J. Zeng, S. Liao, J. Power Sources, 2017, 355, 83-89.

[19] F. Giarratano, G. M. Arzac, V. Godinho, D. Hufschmidt, M. C. Jimenez de Haro, O. Montes, A. Fernandez, Appl. Catal. B, 2018, 235, 168-176.

[20] J. Zhang, L. Ma, M. Gan, S. Fu, Y. Zhao, J. Power Sources, 2016, 324, 199-207.

[21] N. Gavrilov, M. Momcilovic, A. S. Dobrota, D. M. Stankovic, B. Jokic, B. Babic, N. V. Skorodumova, S. V. Mentus, I. A. Pasti, Surf. Coat. Technol., 2018, 349, 511-521.

[22] M. H. Naveen, K. Shim, M. S. A. Hossain, J. H. Kim, Y. B. Shim, Adv. Energy Mater., 2017, 7, 201602002.

[23] I. Spanos, K. Dideriksen, J. J. K. Kirkensgaard, S. Jelavic, M. Arenz, Phys. Chem. Chem. Phys., 2015, 17, 28044-28053.

[24] Y. Wang, H. Luo, G. Li, J. Jiang, Appl. Energy, 2016, 173, 59-66.

[25] B. Li, Z. Yan, Q. Xiao, J. Dai, D. Yang, C. Zhang, M. Cai, J. Ma, J. Power Sources, 2014, 270, 201-207.

[26] B. Y. Xia, H. B. Wu, N. Li, Y. Yan, X. W. Lou, X. Wang, Angew. Chem. Int. Ed., 2015, 54, 3797-3801.

[27] E. Pizzutilo, J. Knossalla, S. Geiger, J. P. Grote, G. Polymeros, C. Baldizzone, S. Mezzavilla, M. Ledendecker, A. Mingers, S. Cherevko, F. Schueth, K. J. J. Mayrhofer, Adv. Energy Mater., 2017, 7, 201700835.

[28] X. Zhong, L. Wang, H. Zhou, Y. Qin, W. Xu, Y. Jiang, Y. Sun, Z. Shi, G. Zhuang, X. Li, D. Mei, J. G. Wang, Adv. Mater. Interfaces, 2015, 2,
1500365/1-1500365/7.

[29] Y. Qin, L. Chao, J. Yuan, Y. Liu, F. Chu, Y. Kong, Y. Tao, M. Liu, Chem. Commun., 2016, 52, 382-385.

[30] Y. Qin, L. Chao, J.J. He, Y. Liu, F. Chu, J. Cao, Y. Kong, Y. Tao, J. Power Sources, 2016, 335, 31-37.

[31] D. Wang, H. L. Xin, R. Hovden, H. Wang, Y. Yu, D. A. Muller, F. J. DiSalvo, H. D. Abruna, Nat. Mater., 2013, 12, 81-87.

[32] Y. Cai, P. Gao, F. Wang, H. Zhu, Electrochim. Acta, 2017, 245, 924-933.

[33] R. Ahmadi, M. K. Amini, J. C. Bennett, J. Catal, 2012, 292, 81-89.

[34] G. Zhang, Z. G. Shao, W. Lu, F. Xie, X. Qin, B. Yi, Electrochim. Acta, 2013, 103, 66-76.

[35] W. S. Jung, B. N. Popov, ACS Appl. Mater. Interfaces, 2017, 9, 23679-23686.

[36] Q. C. Tran, V. D. Dao, H. Y. Kim, K. D. Jung, H. S. Choi, Appl. Catal. B, 2017, 204, 365-373.

[37] B. Lim, M. Jiang, P. H. C. Camargo, E. C. Cho, J. Tao, X. Lu, Y. Zhu, Y. Xia, Science, 2009, 324, 1302-1305.

[38] J. Ying, G. Jiang, Z.P. Cano, Z. Ma, Z. Chen, Appl. Catal. B, 2018, 236, 359-367.

[39] D. He, L. Zhang, D. He, G. Zhou, Y. Lin, Z. Deng, X. Hong, Y. Wu, C. Chen, Y. Li, Nat. Commun., 2016, 7, 12362.

[40] N. Cheng, Y. Shao, J. Liu, X. Sun, Nano Energy, 2016, 29, 220-242.

[41] R. Lin, T. Zhao, M. Shang, J. Wang, W. Tang, V. E. Guterman, J. Ma, J. Power Sources, 2015, 293, 274-282.

[42] Y. Zeng, Z. Shao, H. Zhang, Z. Wang, S. Hong, H. Yu, B. Yi, Nano Energy, 2017, 34, 344-355.

[43] S. Hong, M. Hou, Y. Zeng, Z. Shao, B. Yi, ChemElectroChem, 2017, 4, 1007-1010.

[44] P. Strasser, S. Koh, T. Anniyev, J. Greeley, K. More, C. Yu, Z. Liu, S. Kaya, D. Nordlund, H. Ogasawara, M.F. Toney, A. Nilsson, Nat. 
Chem., 2010, 2, 454-460.

[45] Y. Zeng, X. Guo, Z. Wang, J. Geng, H. Zhang, W. Song, H. Yu, Z. Shao, B. Yi, Nanoscale, 2017, 9, 6910-6919.

[46] W. S. Jung, B. N. Popov, ACS Sustainable Chem. Eng., 2017, 5, 9809-9817.

[47] H. Lv, J. Wang, Z. Yan, B. Li, D. Yang, C. Zhang, Fuel Cells, 2017, 17, 635-642.

[48] E. Lohrasbi, M. Javanbakht, S. A. Mozaffari, Appl. Surf. Sci., 2017, $407,236-245$.

[49] Y. Lu, S. Du, R. Steinberger-Wilckens, Appl. Catal. B, 2016, 187, 108-114.

[50] Y. Y. Rivera-Lugo, M. I. Salazar-Gastelum, D. M. Lopez-Rosas, E. A. Reynoso-Soto, S. Perez-Sicairos, S. Velraj, J. R. Flores-Hernandez, R. M. Felix-Navarro, Energy, 2018, 148, 561-570.

[51] D. C. Dogan, S. Cho, S. M. Hwang, Y. M. Kim, H. Guim, T. H. Yang, S.
H. Park, G. G. Park, S. D. Yim, ACS Appl. Mater. Interfaces, 2016, 8, 27730-27739.

[52] R. Sun, Z. Xia, L. Shang, X. Fu, H. Li, S. Wang, G. Sun, J. Mater. Chem. A, 2017, 5, 15260-15265.

[53] M. Chen, M. Wang, Z. Yang, X. Wang, Appl. Surf. Sci., 2017, 406, 69-76.

[54] R. Alipour Moghadam Esfahani, I. I. Ebralidze, S. Specchia, E. B. Easton, J. Mater. Chem. A, 2018, 6, 14805-14815.

[55] A. Bharti, G. Cheruvally, J. Power Sources, 2017, 360, 196-205.

[56] H. Liu, C. Li, D. Chen, P. Cui, F. Ye, J. Yang, Sci. Rep., 2017, 7, 11421.

[57] Y. Ma, L. Yin, T. Yang, Q. Huang, M. He, H. Zhao, D. Zhang, M. Wang, Z. Tong, ACS Appl. Mater. Interfaces, 2017, 9, 36164-36172.

[58] S. Chen, Z. Wei, X. Q. Qi, L. Dong, Y. G. Guo, L. Wan, Z. Shao, L. Li, J. Am. Chem. Soc., 2012, 134, 13252-13255.

[59] J. H. Zeng, J. Y. Lee, J. Power Sources, 2005, 140, 268-273.

\title{
微量Co修饰的碳载超细Pt纳米粒子的制备及其在燃料电池氧还原催化中的应用
}

\author{
唐雪君 ${ }^{\mathrm{a}, \mathrm{b}}$, 方达晖 ${ }^{\mathrm{a}, \mathrm{b}}$, 矍丽娟 ${ }^{\mathrm{a}, \mathrm{b}}$, 徐东彦 ${ }^{\mathrm{c}}$, 秦晓平 ${ }^{\mathrm{a}}$, 覃博文 ${ }^{\mathrm{a}, \mathrm{b}}$, 宋 微, 郡志刚 ${ }^{\mathrm{a}}{ }^{*}$, 衣宝廉 ${ }^{\mathrm{a}}$ \\ a国科学院大连化学物理研究所, 燃料电池系统与工程实验室, 辽宁大连116023 \\ b 中国科学院大学, 北京 100049 \\ c青岛科技大学化工学院, 生态化学工程国家重点实验室基地, 山东青岛 266042
}

\begin{abstract}
摘要: 质子交换膜燃料电池(PEMFC)具有清洁、高效等优点, 是一种理想的汽车动力电源. 然而, 由于其阴极氧还原反应 (ORR)速率缓慢, 需要使用大量的Pt基催化剂, 导致燃料电池成本居高不下, 严重制约了 PEMFC的商业化发展. 将Pt与过渡 金属 $\mathrm{Fe}, \mathrm{Co}, \mathrm{Ni}$ 等形成合金, 对表面Pt原子的几何结构和电子结构进行调变, 可以有效提高催化剂的活性, 实现Pt用量和燃 料电池成本的降低. 但是目前合金催化剂多采用溶剂热、浸渍-高温退火等制备方法, 使用有毒有害试剂和难清洗的表面活 性剂, 且过程复杂、能耗高, 不利于大规模化生产. 此外, 合金中过渡金属占比高, 在燃料电池工况下, 大量过渡金属溶解, 加速了膜的降解, 导致实际PEMFC性能的降低. 对此, 我们探索了一种简便有效的方法制备高活性、高稳定性的碳载Pt-Co 催化剂. 在没有添加表面活性剂的情况下, 采用嗍氢化钠辅助乙二醇还原法合成了具有超小尺寸和均匀分布的Pt-Co纳米 颗粒, 后续酸刻蚀处理去除不稳定的Co原子, 重组双金属纳米颗粒的表面结构形成富Pt壳层, 进一步提高了催化剂的活性 和稳定性. 通过电感耦合等离子体、X射线粉末衍射、透射电子显微镜、高分辨透射电子显微镜、高角环形暗场-扫描透 射-元素分布及光电子能谱等物理表征证实了微量Co改性的碳载超细铂合金纳米颗粒的组成和结构. 进一步对催化剂进 行旋转圆盘电极和单电池测试, 结果表明, $\mathrm{Pt}_{36} \mathrm{Co} / \mathrm{C}$ 具有明显高于商业化 $\mathrm{Pt} / \mathrm{C}$ 的有效电化学活性面积和电池性能. 此外, 加 速衰减测试和衰减前后的电镜图片表明, $\mathrm{Pt}_{36} \mathrm{Co} / \mathrm{C}$ 催化剂的稳定性相较于 $\mathrm{Pt} / \mathrm{C}$ 亦有所增强. 分析 $\mathrm{Pt}-\mathrm{Co} / \mathrm{C}$ 催化性能提高的原 因, 主要归于以下三点：(1)催化剂纳米颗粒在载体上分布均匀, 且具有超小的粒径尺寸, 提供了大量的三相反应界面位点; (2)双金属配体和电子效应的协同作用, 降低了氧化物质在催化表面的吸附能力, 加速了 ORR的电催化动力学; (3)酸蚀刻导 致的不稳定 $\mathrm{Co}$ 的溶解及催化剂表面结构的重排, 形成了富 Pt壳层结构, 有利于提高催化剂的稳定性. 这种简单有效的合金 制备方法可以在电催化领域推广使用.
\end{abstract}

关键词: 质子交换膜燃料电池; 氧还原反应; 超细Pt纳米粒子; 微量Co修饰; 改进的乙二醇还原法; 酸刻蚀

收稿日期: 2018-12-01. 接受日期: 2019-01-11. 出版日期: 2019-04-05.

*通讯联系人. 电子信箱: zhgshao@dicp.ac.cn

基金来源：国家重点研发计划(2016YFB0101208); 国家自然科学基金(21576257); NSFC-辽宁联合基金(U1508202); 中国科学院战略性先导科技 专项(B类) (XDB06050303).

本文的电子版全文由Elsevier出版社在ScienceDirect上出版(http://www.sciencedirect.com/science/journal/18722067). 